\title{
MUTUKA NYAKUNYTJA - SEEING A MOTORCAR
}

\author{
A PITJANTJATJara TeXT \\ JACKY TJUPURULU WANGKANYTJA
}

\author{
Related by Jacky Tjupuru \\ Translated by Bill Edwards
}

\section{Introductory notes by Bill Edwards}

This story was related by Jacky Tjupuru, and recorded, at Amata community in the northwest of South Australia on Sunday, 12 August, 1973. He had previously told me part of the story and I took the opportunity to record it when visiting Amata from Fregon community, where I resided. The storyteller was a Pitjantjatjara man, born approximately 1907 in the Deering Hills, south of the Mann Ranges. The incidents described in the story took place when he was a young man, approximately 1930 . He married and he and his wife had a son and three daughters. A classificatory son who was orphaned was also raised in the family. The family lived at Ernabella Mission in the eastern Musgrave Ranges following its establishment in 1937, the children attending the school. The eldest daughter became one of the first Pitjantjatjara school assistants. Jacky Tjupuru's wife and their eldest daughter died in the mid-1960s.

Jacky Tjupuru regularly visited his traditional homelands from Ernabella and became a guide to several patrol officers and researchers. He lived at Amata Community in the western Musgrave Ranges during the 1970s and spent some periods camping at Kanpi, on the southern side of the Mann Ranges, close to his birthplace. His last years, before his death in the mid-1980s, were spent at Ernabella and in the Hettie Perkins Hostel in Alice Springs. I met him soon after arriving at Ernabella in 1958, later accompanied him on several visits to traditional Pitjantjatjara sites and camped with him at Kanpi several times in his later years. As he is deceased, care must be taken in the use of his name, but his sons have given verbal permission for the use of the story. In recent years there has been some relaxation of the earlier Pitjantjatjara prohibition on referring to dead people. Pitjantjatjara people are expressing increasing interest in preserving oral histories and photographs.

The story provides several insights into the nature of culture contact in the far northwest of South Australia in the 1920s and 1930s. Most of the area referred to in the story was included in the North-West Aboriginal Reserve gazetted by the South Australian government in 1921. This forestalled further pastoral expansion and provided some protection for the Pitjantjatjara people from earlier incursions into their land by prospectors and adventurers. However, distance from police and Protection Board offices, limited oversight of the reserve. Pastoral blocks just outside the reserve were used as base camps by prospectors and 'doggers', white men who travelled into the Reserve with camels to trade

Bill Edwards is a Senior Lecturer in the Aboriginal Studies and Teacher Education Centre, University of South Australia. He was Superintendent of Ernabella Mission from 1958 to 1972, and Pitjantjatjara Parish Minister based at Fregon in 1973 and at Amata from 1976 to 1980. 
ABORIGINAL HISTORY 1994 18:2

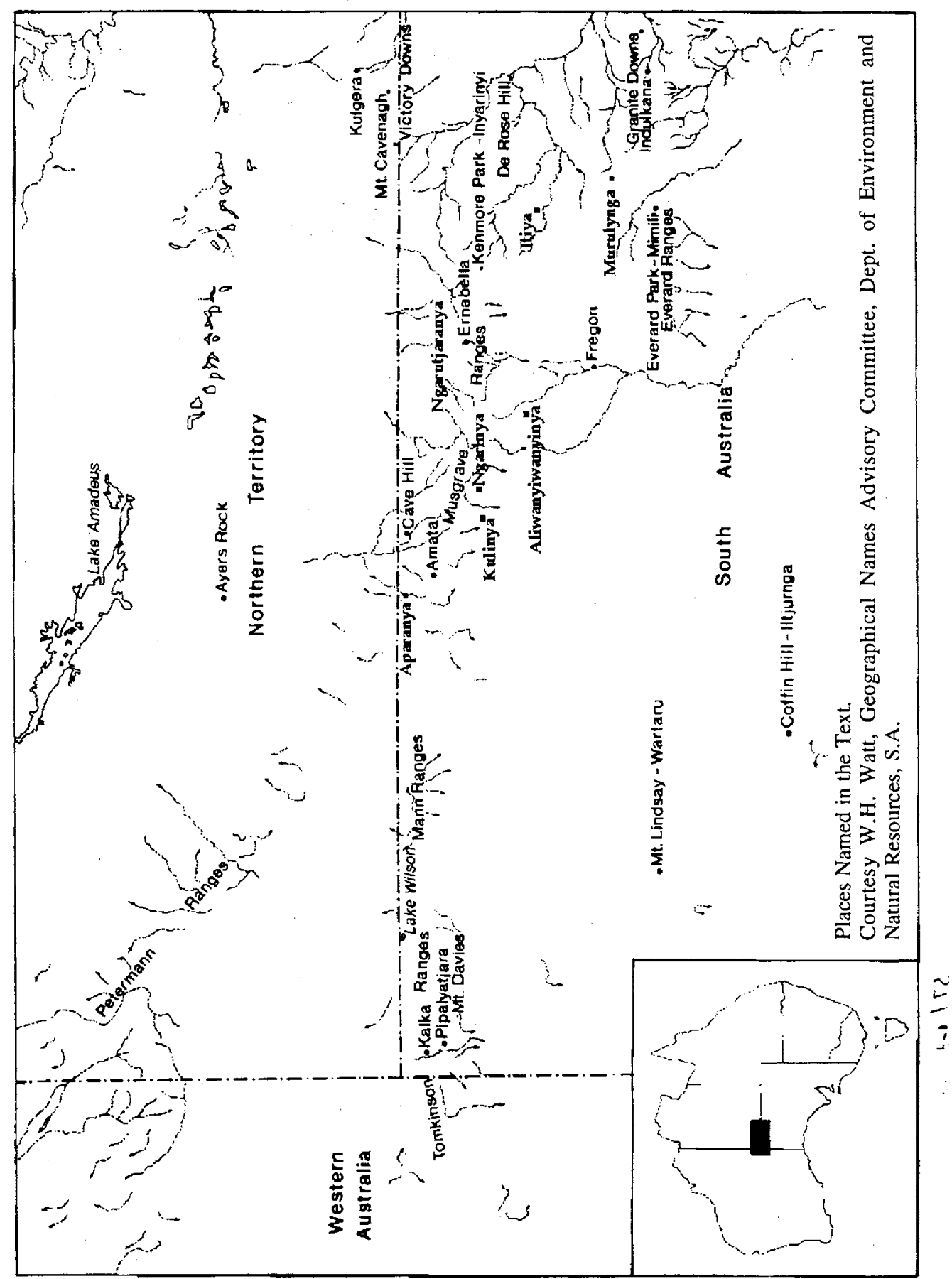




\section{SEEING A MOTORCAR}

with the Aboriginal people for dingo scalps. The government paid a bounty of seven shillings and sixpence on the scalps. Food, such as flour, tea and sugar was given to the Aborigines by the 'doggers' in return for the scalps. According to this story, Jacky Tjupuru had met one of these men, whom he identifies as Ted Colson, and with some of his relatives accompanied him on his return journey from Apara, a water spring, north-west of Amata to Moorilyana, a pastoral outpost, north-west of the site of Indulkana community. Colson's trade supplies were exhausted on the return journey and this led to an argument with two men who had scalps they wished to trade. The presence of Jacky and his kin obviously provided some protection for Colson from the wrath of the disappointed men.

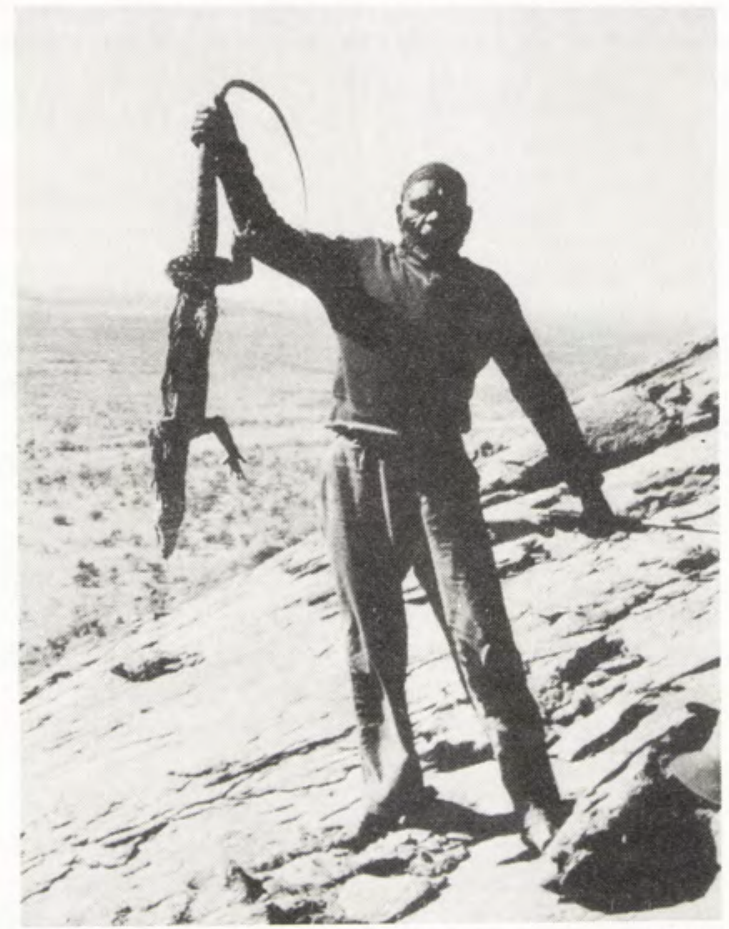

Jacky Tjupuru at Mt Lindsay (Wartaru) in the mid-1960s.

Courtesy Bill Edwards.

Edmund Albert (Ted) Colson (or Carlsen, 1881-1950) was born at Richmans Creek, near Quorn, South Australia, the eldest of the eight children of Peter Errick Colson (a farmer who had emigrated from Denmark) and his second wife, Ellen Amy, nee Lines. In 1896 he sailed with his father to Western Australia where they pushed a wheelbarrow with their possessions to the Coolgardie goldfields. He married Alice Jane Horne at Kalgoorlie in 1904. They moved to Victoria in 1917, where he worked on the construction of the Maroondah Dam in the Dandenong Ranges. In 1926 he commenced a motor service between Healesville and Melbourne. In 1927 he moved to Oodnadatta in South Australia to work on the extension of the railway from Oodnadatta to Alice Springs. He ventured west on several occasions, in 1928 exploring west of the Goyder River and later, opening up the route through the Musgrave Ranges to Opparinna (Aparanya) Creek. In 1930 he was cameleer on Michael Terry's expeditions to the Petermann and Tomkinson ranges. On 28 December 1930, Terry at Day's Gully in the Mann Ranges, gave Colson food for two and a half 
weeks for his return journey to Lambina or Moorilyana. Terry wrote: 'He is happy to follow slowly for he has several times been out here only with a myall. Nor has he any large load of tucker to incite the lawless blacks to take it from him.' ${ }^{1}$ In 1931 Colson leased Bloods Creek station at Abminga, north-west of Oodnadatta. He collected information on Aboriginal life and mythology and corresponded with Elkin and Tindale. On 17 November 1931 he wrote to Tindale; 'I have recently returned from the Everard and Musgrave Range country,' and on 6 March 1932; 'I will not be going out West again until May or June. ${ }^{2}$

In 1936 Colson and an Antakirinya man, Peter, undertook the first camel expedition across the Simpson Desert. His journal of that expedition is held in the Mortlock Library, Adelaide. There are no records of earlier journals which might have enabled me to find a reference to his journey with Jacky Tjupuru. I assume that it was one of Colson's westward expeditions approximately 1930 . Colson later established the Colson Trading Co. at Finke in the Northern Territory.

Jacky Tjupuru and his kin came from land which they knew intimately. In their society status depended largely on this knowledge of the land, and of the resources, stories and rituals associated with it. Traditional learning revolved around such knowledge. Pitjantjatjara people took pride in the fact that they were ninti, or knowledgeable, of all things in their environment. Then they found strange people, species and objects introduced into this environment, things about which they had no knowledge. Reference is made in the story to the introduction of new foods, such as onions, which were thrown aside as rubbish because they were eaten raw and tasted bad. The learning of tracking skills was an integral part of education. A great amount of information could be obtained by reading the signs of tracks on the ground. With the introduction of horses, sheep and other new species, unfamiliar tracks appeared. Thius Jacky Tjupuru could not recognise sheep tracks and wondered if they were made by large echidnas. Once they mastered these new tracks they became more skilled in recognising these tracks and their significance than the whites who had introduced the new species. Reference is made in the story to the use of Aboriginal people as shepherds, an example of the widespread employment of the people in the pastoral industry in that era.

The story-teller's lively description of his first sighting of a motor vehicle is the central focus of the story. Motor vehicles are now an ever-present and central part of Pitjantjatjara life. The first vehicle owned by a Pitjantjatjara person in the region was a second-hand Land Rover purchased in 1961, by a man who was employed on a water driling rig at Ernabella. He was given a small loan by a staff member to enable him to purchase the vehicle. As he was earning more than other workers he was able to repay the loan. By the end of the 1960s the number of privately owned vehicles had proliferated. Less than thirty years earlier the experience of a motor vehicle had brought a serious challenge to Tjupuru's view of the world. He had grown up in a world in which all phenomena shared in the legacy of the Tjukurpa, or Dreaming. Kurunpa or spirit, which had animated all living species, inhabited the land, rocks and other natural phenomena and people believed they could communicate with all things in their environment, as all things possessed kurunpa. This noisy apparition which came towards him like a moving rock had not come from the Dreaming. When, in fear, he sought to communicate with it, Tjupuru was told that it could not hear him and was not angry with him. The motor vehicle obviously had no kurunpa.

1 Terry 1930, p.104.

2 Colson Papers, Anthropology Archives, SA Museum. 


\section{SEEING A MOTORCAR}

Humans controlled it by technology rather than by ritual. His fear that he would fall from the vehicle has a sombre overtone in retrospect, in view of the number of Pitjantjatjara people killed in motor accidents in recent years. Added poignancy to the story relates to the fact that Ted Colson was killed in 1950 in a motor accident when driving a new Land Rover from Adelaide. The vehicle hit a power pole near Balaklava, approximately 100 kilometres north of Adelaide.

As in this story, reference is made in several oral histories to the practice in that era of sending messages or letters with Aboriginal people. Official mail services were provided to outlying pastoral settlements from centres such as Oodnadatta by contractors using camels. Beyond the limits of these services apparently it was commonplace to use Aboriginal people to convey letters to whites who were living or travelling further afield. In one story there is reference to a letter being given to a young man at an outstation between the present sites of Ernabella and Amata. The young man immediately burnt it. In another story there is reference to a letter being received at Ernabella when it was a pastoral lease. It stated that there was a white man starving in the Petermann Ranges. My informant, the late Billy Kulyuru, stated that as a boy, he accompanied a man of mixed European and Aboriginal descent, Gilpin Ward, and others, on a long journey to take food to the man. When they arrived in the area, the Aboriginal people said that they were too late. The man, Harold Lasseter, had died. The present story provides further evidence of this practice of sending letters with Aboriginal people. 


\section{THE TEXT}

Aparalanguru ngayulu, ngayuku kami, ngayuku ngunytju kulu pitjangi. Mununa ngayuku malpa, wati walypala katingi. Ka Kaminya, Taritjanukunu, Aipinya, ngayuku kulypalpa, Ruringkukunuku kuri,

Ruringkukununya wiyalpi, wati yangupala, munu ngayulu Alkarkarinytjala ngaringu. Ka ngali uru pulkangka nyinangi.

Munuli nyanga paluru ngali ngaringu, mununa munga winki mai puritana ungu ngayuku ngunytju, tjitji, ngayuku kami Taritjanukunu. Ka walypala paluru ngalkula pitjangu, kana watjanu: 'Purkara pula pitjama. Ngayulu ngali ananyi ngura parari ngarinytjikitja, palu nyupali purkara pitjama - Kamula nyangatja luuta pulkatjara Tjinguru putu tatinma - tjinguru tjirkanma.' Kana ngayuku kami alatji watjarana mapitjangu, ka mala pitjangi.

Kana Marangakanaku ma-pitjangi, munuña anyina tjuta ungu palumpa mungartjiku tjapaku, tjapaku katinytjaku, mununa palurunku kulkungka pauntja watjaliyangkuna ungu kutju. Ka paluru wanka arkanu munu mirara watjanu: 'Munta, kurani ungu.' Munu paluru wantikatingu paikingka panangka, raputji waningu mai nyaratja paura ngalkuntja wiyangku.

Ka nganana parari ma-pitjangu, mununa nyangu, ngayuku kuta kutjarana nyangu, kutjarana pulanya nyangu, Mintunkunu kutjara. Ka pula pikaringu walypalaku palumpa malanyputu wiya, palu palumpa kutaputu pika pulkaringu, munu pula nguwanpa kultunu. Kaña ngayulu payiningi, ka mai miri putu ungkula mai wiyanmankunyangka pika pulkaringu Marangakanala.
A long time ago I was travelling from Aparanya with my grandmother and mother. I was bringing my friend, a whiteman, and also my grandmother, Taritjanukunu, Ivy, and my uncle, Ruringkukunu's husband. This was before he married Ruringkukunu, when he was a young fellow. I camped at Alkarkarinynga and we two stayed at a big waterhole.

We two camped there. In the morning I gave some bread to my mother, a child and my grandmother Taritjanukunu. After the white man had eaten he came and I said: 'You two come slowly. We two are going to a distant place to camp, but you two come slowly. This camel has a big load. Perhaps we can't mount it. It might buck.' Having said this to my grandmother, I went off, and she followed.

I was travelling to Marangakana and I gave her some onions in the evening, so that she could take them for supper. I just gave them to her without telling her to cook them in ashes. She tried them raw and shouted out: 'Hey, You gave me something bad.' She left them in a bag on the ground. She threw that food away as rubbish, without cooking and eating it.

We travelled on a long way and I saw two of my older brothers. I saw those two sons of Mintun and they were angry with the white man - not so much the younger one but his older brother was very angry - and they almost speared him in the ribs. I sent them off. They were angry because he couldn't give them flour for their dingo scalps at Marangakana. 


\section{SEEING A MOTORCAR}

Ka paluru ngulunguluringu kulira; 'Tjingurunini kultura ilunankuku.' Mununi ngayula watjaningi: 'Yaaltjingani nyangatja?' Kana watjanu: 'Wampanti.' Nguntina watjaningi, palumpa pika pulka nguwanpa tjilira pulkangku kultunu wati nyanga paluru. Ka paluruni watjanu: 'Kamula witila walangku munu pakaltjingala.' Munu paluṛu ngulungku ngarala watjaningi, munu kutjungka panya mapalku tatinu.

Ka ngayulu panangka pitjangu tjina, ka pakaltjinganu munu mapalku tatirali ngura nyara Kulilakutu ma-pitjangu ruutangka, mai wiyali pitjaliningi, mai tjukutjuku mulartjara, tjukumulapa, palu raitji kutju, raitji, paritji kulu.

\section{Kali ngura nyara Ngarila tjarulta ngaringu} ruutangkalta mungaringkunyangka.

Munu tii tjikiningi, kapati ngayunya ungu, kunparatji tjukumularta ungkula watjanu:

'Iluntara.' Kana watjanu: 'Wiya, wiyaringu pula, wangka wiyaringu ngayuku kutaputu.' Tjinguru wanalkatingi kulata pulkaku nguluringu, kulata tjilira winkiku. Ka mungangka tjulpu panya nyaa wangkangi? Kurkurpa, kurkurpa wangkangi. Ka kuliningi; "ngayunyanti warkikatinyi,' wati nyanga pirantu, munu nyangatja iluntanu uwankara kunparatji, tili nyakula pitjala kulatangka wakantjaku-tawara.

Kana watjanu: 'Wiya, wati wangkanytja wiya, nyara paluru ngarinyi, nyinanyi tjinguru. Palu mai paltjatjiritja wangkangi, mai wiya nyinara.'
He was very frightened thinking, 'Perhaps they will spear and kill me,' and he said to me: 'What is this about?' I said: 'I don't know.' But I was lying. That man had been angry and nearly speared him in the side. $\mathrm{He}$ said to me: 'Get the camels quickly and get them moving.' He was frightened and mounted one quickly.

I came on foot and he got moving straightaway and we two were riding and going on the track to a place named Kuli. We were going along with no flour, or just a small amount, and with just rice and also porridge.

We camped on the track below Ngarinya in the evening.

We were drinking tea. He gave me a cup of tea, and having given me a little firewood said: 'Put the fire out.' I said: 'No. It's all finished with those two. My two older brothers have stopped talking.' Perhaps he thought they were following and was afraid of their spears. During the night a boobook owl made a noise. The white man was thinking, 'It might be them cursing me.' $\mathrm{He}$ extinguished the fire in case they saw the flame and came to spear him.

I said: 'No, that's not a man speaking. He is probably lying down. He was only talking like that because he was hungry and had no food.' 


\section{ABORIGINAL HISTORY 1994 18:2}

Kali munga winkili ila taimapira wantinytjatjanungku munga tjukutjukungka pinpatja ngalkuntjikitjangkuna walatjunu kamula munu mapalku wanara mantjinu mai mungura, mai ngalkula wañara mapalku mantjira karpirampala warpungkula Aliwanyuwanyukulta ma-pitjangi.

\section{Aliwanyuwanyunya kantura pitjangu mina} tjutinu, munu tii tjikintja wiya ngura nyara Uwalinyila wanu para-tjarpangu munu Tilunkitjangka tina ngalkunu, maa-pakanu Tilunkitjanguru, Tilunkitjangka ngalkula maa-pakanu Ngarutjaraku para-ukalingu Anapalanya wiyala alatjikutu piruku anu apu-wanu, paluru ngulu, wati nyara kutjarangku nguwanpa wakanyangka ngulu anu

Alatjingarala nganala Ngarutjarala nyaa nyangu? Nyangatja Mickaku mama nyinangi, ngayuku kuta. Kala wirkanu munula piruku tina tjunu kapatiltala munu ungu, munula tjikirampa papa miritjaralta ma-pakanu piruku, tjungulta Kunaunpulala ngaringu, mai mungartji ungu papangka, tjukutjukulta wiyangkalta ungu munu watjanu: 'Mai wiya, palu palyana tjukutjuku.'

Ma-pakanula ngarira munga winki karpira ma-pakanu munu Tjaltulalta, Tjaltula tina ma-ngalkunu, Tjaltula munkara, Tjaltunyala wiyatu, Tjaltula nyinanytja wiya mapitjangu. Munula Kinmula tjangati Tjuwampilala wanu-pitjangu.

Munula Kinmunya kantura pitjangu mungartji munula ngura nyara Alkaritjangka ngaringu. Munu panyala ma-pitjangilta nganakulta? Itiyakulta ngarirampa, munula Itiyala munkara Takakuwilangka munkara ngaringu tamangka munkara, mungartjirira nyinngangka mantu.
We had tied up the camel nearby so early the next morning we untied it and let it loose while we had breakfast and as soon as we had eaten I followed it and brought it. After eating, following and catching it we loaded it quickly and went off to Erlywanyawanya.

Having reached Erlywanyawanya we got some water but without drinking tea we went on by way of Uwalinyi and went into Tilunkitja and ate dinner, and went off from Tilunkitja. We went on from Tilunkitja, having eaten there, and went down around Ngarutjara but avoided Ernabella. We again followed the hills because he was afraid. Because those two men had almost speared him he travelled in fear.

And as we were doing this, what did we see? Mick's father, my older brother was camping there. We arrived and put out some more dinner and tea and gave him some. After having a drink we went off again with some dingo scalps. We camped together at Kunaunpu. He (the white man) gave a small amount of flour in return for scalps in the evening and said: 'The flour is finished, but I can give just a little.'

Having camped there we got up in the morning, loaded up and went off to Tjaltu and ate dinner at Tjaltu - just the other side of Tjaltu, not right at Tjaltu. We did not stay at Tjaltu but moved on and this side of Kenmore Park we went by way of Swamp Well.

We came to Kenmore Park in the evening and camped at Alkaritja. Then where did we go? We camped at Itiya (Echo Hill). We went past Itiya and camped the other side of Doctor's Well, the other side of the dam, and it was very frosty in the evening. 


\section{SEEING A MOTORCAR}

Munula munga winki mulapa karpira mapakanu mununa nyangu tjiipi tjina panya, mununa watjanu: 'Nyaa nyangatja, nyanga alatjimpa? Nyaa tjuța nyangatja?' Mununa mitura nyangatja tjuta mulapa wañanu. Kuka nyaatja nyangatja nyangankutu ngura parari mitulkatinytja mitulkatinytja wananingi nyangakutu manti ngarinyi.

Ka paluru watjanu: 'Wiya. Wala pulka palatja, ma-wanti, ngura parari, ngurakutu, ngurangka ngula utira nyawa, ngurangka ngarala Murulytja nyawa, palu palatja maiku anu, wati kutjungku ma-wananingi, minymararangku mituningilta, wampaku, ngura nyarakutu wanu parari wanungku wati ngalkuningi.'

Kala pitjangulta, ka Tommylu watjanu: 'Ngalya pitjala nyawa panya palunya, pitjala nyawa ngurangka nyanga ngarala waninyi.' Kana utira nyangu mununa watjaningi; 'Nyaa purunypa nyangatja? - Tjirilya purunypa, tjirilya purunypa nyangatja? Wiya tjirilya tjukutjuku palu nyangatja wara, kuka pulkanya.' Mununa nyakula nyakula nyakulampa ngaringulta wangkara waningi pala.

Alatjingarampala ngarira munga winki manyinarampa pinpatja ngalkula nyinarampa, ka wati kutjupa piranpa ngalya-pitjangi munu watjanu: 'Nyuntu katiku nyanga kamula kutjara maikutu ukiri pulkakutu nyangatja nanikutangku nyaapangku ngalkula wiyanu, tjiipingku ngalkula wiyanu, palu maikutu kati munu ngula kapitjanura nyanga palunya tjinguru kamula kutjupangku pikatingku nguluru wanalku, ka pula malaku pitjaku mai wiyakutu. Palu nyuntu atunymara munu ngula taimapira wantima kapi ungkula.'

Kaña kutju palunyatu kulinu ngura nyangatja yiwalakutu nyara ankuku Intalkalakutu, palu Mingkutjanuwilala kanyintjaku, kala palulalta kanyiningi.
Early next morning we loaded up and moved off and I saw footprints of sheep and I said: 'What this? What are these?' I tracked and followed them. I kept tracking and following, wondering what animals they were and thinking to track them to where they were lying down.

He said: 'Don't! They have hurried off a long way to their camp. You will see them clearly in camp later at Murulynga. They have gone off for food and a man is following them and he and his wife are following their tracks. I am not sure where they are. They could be a long way off, moving around eating.'

We went there and Tommy said: 'Come here and see them. Come and see them standing around in the camp.' I saw them clearly and I said: 'What are these like? They are like echidnas. Are they the same as echidnas? No, echidnas are small but these are tall. They are big animals.' I looked and looked at them and camped there and talked about them.

After this had happened we camped and in the morning we ate breakfast and were sitting there, and another white man came and said: 'You take these two camels out for food, to green grass. The nannygoats and sheep have eaten it here and finished it. Take them to some food and later on hobble them in case perhaps a wild camel will frighten and follow them, and they will come back to where there is no feed. But you look after them and later on leave them tied up after you give them water.'

I heard him say that he was going to a place, Indulkana, where there was a house, and to look after them at Mingkutjanu Well, and we were looking after them there. 


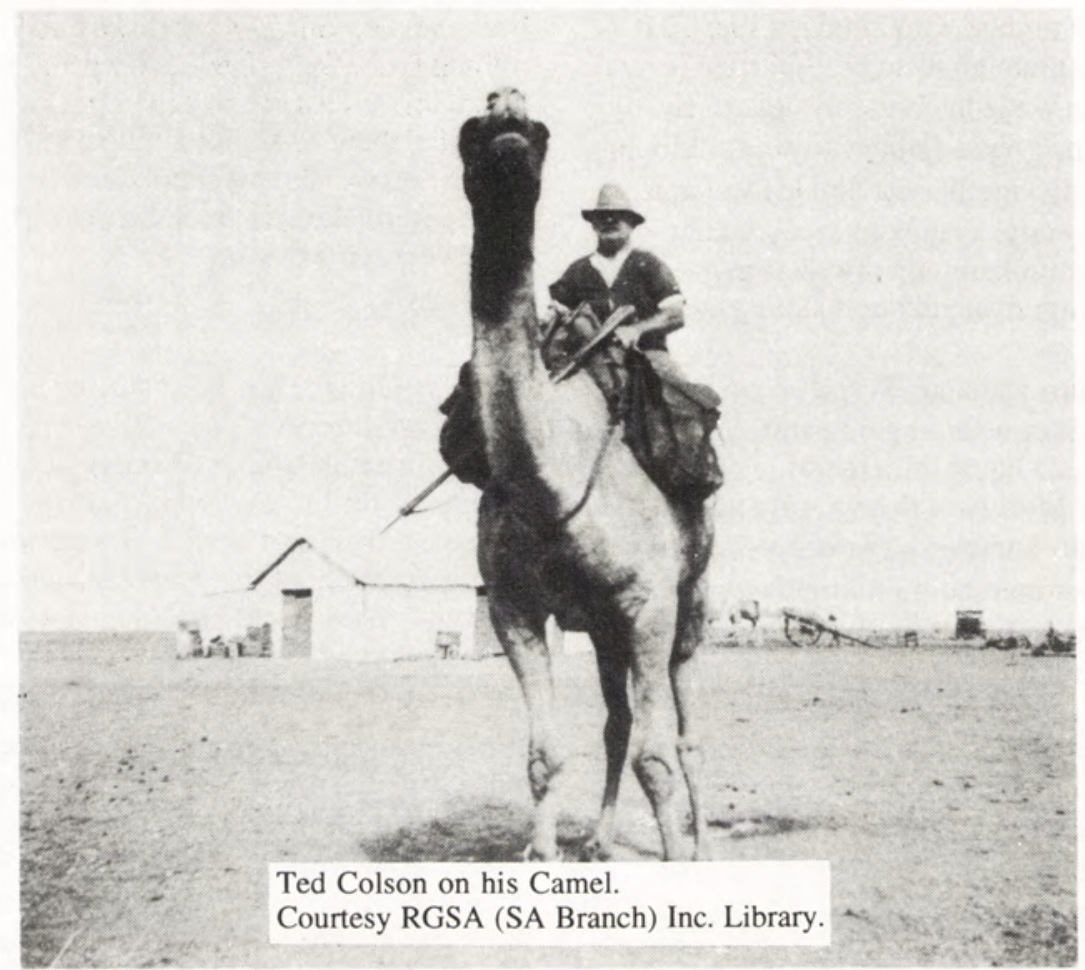

Kanyira kanyirampanal ngaringu mankurpa, piruku ngarirampa kulinulta. Mununa kuliningi kamula manti ngaurmananyi pikampa, tjinguru patjani kamulangku - ur, ur, ur, ur - kana kulira kamulanti ngaurmankunyangka. Ilaringumpa nyangatja, ilaringumpa nyangatjal, nyanga lurngumpal. 'Nyaa nyangatja? Lurngu nyangatja. Untulkulanya.'

Kana punungka para-kumpinu, punungka wati-kumpinu, puțu para-kumpira.

Nyangatja wati-katira nguwanpa ngalyanyinatjunu. Kana kumpira ngarala nyangangi pununguru nyakula nyakula alatjingara ngalya nyinatjunu.
Having camped there three nights while looking after them I was lying there and heard something. I was thinking it might be a camel growling angrily. Perhaps another camel is biting it - ur, ur, ur, ur - I was thinking it was a camel growling. This thing came closer, this rock-like thing. 'What is it? It is a rock. It will crush us.'

I hid behind a tree. I was hiding beside a tree because I was unable to hide right behind it. This thing was brought around close and was stopped and I was standing hiding and looking from the tree and as I was watching like that they stopped it there. 


\section{SEEING A MOTORCAR}

Walypala panya mungatu nganana nyinanytjanyampal nyangatja wirkanu. Ngananyampa? Teddy Colsonanyampa. Paluru pitjala watjanu: 'Wiya, mutuka wiru, ngulu wiya, wiru nyangatja.' Kaya pampuningi nintingku - Nganalu? Winitjalu. Ka ngayulu ngurpangku, ka Tommynya panya ninti kutju paluru, palu ngayulu ngurpangku nyangulta.

Ka watjanu: 'Wiya, nyangatja pikati wiya, nyangatja piti tatira pitjalinkupai, munturtjingani nyangatja walypalangku, palu watingku paluru wangkanytja wiya. Paluru wangkara, paluruntju wangkanytja wiya, paluru nyinara wangkanytja wiya.'

Alatjingarampa watjanulta: 'Uwa, tatilaya, kala ara.' Kaña ma-tatinu purkara purkara. Ka watjanu: "Wati, wala pulka tatila ankuku, kukakula mapalku ara.' Winitjaluni watjanu, kana mapalku ma-tatira palunya ampura nyinangi, munuli nyinangi. Ka watjanu: 'Pikati wiyampal nyangatja, pikati wiya. Nguntin nguluringanyi.'

Ka ma-katingu, kana ngunti alatjingara nyinangi kulira ngurangkatuntila nyinanyi, palu nyangumpanal ngura pararila nyangatja ma-pitjanyi nyaratja. Palu nyinanytjaku kantjana nyinara munturmankunytjaku kantja. Palu mapalku ma-pitjangu paluru. Kana watjanu: 'Pararimpalal nyangatja anu, wiya punkatjingalkunitju.' Ka watjanu: "Punkuntja wiya nyangatja, ngati wiru.' Nguntina kulilpaiku kantja watjanu: 'Wiya, watjala wanyu ka purkara pitjama mutuka nyanga, mutuka ma-watjala, ka purkara pitjama.'
It was the white man who was with us the other day arriving. Who was he? Teddy Colson. He came and said: 'Don't worry. This is a very good motor car. Don't be scared. It is really good.' They were touching it knowingly. Who was it? Winitja. And I was ignorant. Tommy also knew about it but I looked at it in ignorance.

He said: 'Don't worry, this thing is not angry. This is a dish that you climb into and move about. The white-fellow makes this thing go but the man does not just talk to it. Talk to it and it does not talk back. It just stays there without talking.'

He said to me: 'Yes, all climb in and let's go.' I climbed up slowly. He said: 'Hurry up man. Get in and we will go. We will go straightaway to hunt for meat.' Winitja said this to me and we climbed in straightaway and we were sitting there and I was clinging on to him. He said: 'This thing is not angry. You are frightened because of ignorance.'

He took us away and I was ignorantly thinking that we were still sitting at the camp, but I saw the camp moving away in the distance. It was as if we were sitting there making a noise. But it went off quickly, and I said: 'We have gone a long way in this. Don't let it throw me out.' $\mathrm{He}$ said: 'You won't fall from this. We are sitting down low here.' I talked ignorantly like this: 'No. Talk to it so that this motor car will move slowly. Talk to the motor car and it will go slowly.' 


\section{ABORIGINAL HISTORY 1994 18:2}

Ka watjanu: 'Wiya, nyangatja kulintja wiya. Tjingurula puțu wangkama, ka paluru wiya pitjalinama - wirtjapakanma. Palu wati nyangangku uritjingani, wati nyanga pirantu nyangatja katinyi, wala pulkara palu. tjinguru paluru puțu pitjama.' Alatji watjanu, palu ngayulu kulinu: 'Wiya, paluru nyangatja ananyi, ka wati nyangatja tatinyangka mapalku ma-pitjangu, wati nyanga nganana.'

Kukaltala rapitalta nyinatjura pauningi. $\mathrm{Ka}$ paluru kutju nyinara munturmankunyangka ma-wararakatingu. Ka ngayulu puțu mapitjangi, ma-wararakatingi rapitaku. Ka ninti paluru kutju ma-pitjangu, ka ngayulu ngatalpa nyinangi. Alatjina kuliningi, 'punkalkuna.' Ngurpa pulkana mulapa ninti tjukutjuku nguwanpa ngaranytja wiya.

Ngayulu ngurpa alatjitu. Nyara palulaltana kutjupa itingka nyinanytja wiya, kamula tjuta kutju, nyanytju kutju.

Palu tjinangku, tjinangkuya lita tjuța katingu, litatjara tjina pararinguru pitjapai Murulyku, ngura nyara Intalkala, Wanytjapilalanguru. Wati kutjarangku katipai mai kulu ungkul'iyanyangka. $\mathrm{Ka}$ nganana mantjira katipai Murulyku.

Kamulatjarangkulanya watjalpai: 'Nyangatja kati wati.kutjupa nyangakutu nyinanyi kamulatjara.'

Kala nyanga-wanungku katipai, munula wañara wanara nyangangka wirkakatipai, mai tina ngururpa ngalkula, maitjara wirkankupai. Ka paluru patara mai purita ungkupai kala ngalkuningi, ka walkatjura piruku malakungku ungkul'iyalpai.
And he said: 'No. This thing can't hear you. We can't speak to it. It does not go around by itself. This man makes it move around. This white man takes it around quickly but this thing can't just go on its own.' He said this to me and I thought: 'No. This thing just goes, and a man gets in and immediately it goes off with us.'

We stopped it and were shooting rabbits. He jumped down on his own while the engine was running but I couldn't jump off to go for rabbits. He knew all about it and went off but I stayed back. I was thinking: 'I will fall down.' I was completely ignorant about it, not even a bit knowledgeable. I was really ignorant. I had not been near them before, only near camels and horses.

They brought letters on foot. They would come a long way on foot with letters to Murulynga from Indulkana and Wanytjapila. Two men would bring food also which had been sent, and we would receive it and take it to Murulynga. The man with camels would say to us: 'Take this to the other camel-man.'

We would bring it this way and after following and following him, would arrive with the food, having eaten dinner on the way. Having waited for us he would give us some bread and we would eat and after he had written a letter he would send us back again. 


\section{SEEING A MOTORCAR}

Kala pirnku malakungku katipai, munula piruku nyangatja katipai wati panya palulakutu panya nganmanytju lita ungkul'iyantjalakutu. Kani mai nyangangku ulu purita tinaku ungu kana maitjarangku katipai piruku wati kutjupaku malaku nyinanyangka nyarakutu Anapalalakutu. $\mathrm{Ka}$ nyanganguru mai pulk ungkul'iyalpai ruuta nyangangka.

Kala maitjara maa-ngaripai munu piruku ila ngarira ma-wirkakatipai mai winkitjarangkutu. Ungkunytja wiya kamulatjarangkula - nganana tjina alatjitu ankupai. Murulykula ngalya-katira Wanytjapilalanguru Intalakala ungu. Ka Intalkalanguru tjitji kutjarangku ngalyakatingu munu ngayula wirkakatingu. Ka ngayulu ma-katingu, Murulytja tjarpatjunu kamulatjarangkula.

Tjitji kakararatja tjuta wati panya nyaranpaya nyinangi Intalkala. Paluru tjana katipai tjinangku, kamula wiyangku ruutangka tarara ankupai. Alatji nganampa ngarangi ngayuku nyanga. Alatjituna wangkanyi.
We would take it back again and we would take it back to the man who had first given us a letter. He gave me flour and bread for dinner and I would again take flour to another man who was living back at Emabella. He would send a lot of food from there on this road.

We would camp out with the food and after camping out again nearby we would arrive there with all the food. We didn't have camels - we would go on foot. Having carried it from Wanytjapila for Murulynga we handed it over at Indulkana. Two children brought it this way from Indulkana and brought it to me, and I took it on and delivered it at Murulynga to the camel-man.

Some children from the east were living with those men at Indulkana. They would take things on foot, not on camels, and move quickly on the road. This is how it was with us and with me. I have finished talking.

Acknowledgments: Staff members of the Mortlock Library, (State Library of South Australia), Anthropology Department of the SA Museum and Royal Geographical Society of Australasia (SA Branch) Inc., for access to their collections of Colson Papers; the Royal Geographical Society of Australasia (SA Branch) for permission to use the photograph of Ted Colson; Professor Colin Horne for access to his collection of Colson papers; Bill Watt (Geographical Names Board, SA) for locality map.

\section{LIST OF REFERENCES}

Colson, E.A. 1940. The First Recorded Crossing of the Simpson Desert from West to East. Proceedings of the Royal Geographical Society of Australasia (South Australian Branch) Inc., Volume XLI Session 1939-40, (November 1940 pp. 10-21.

Colson, E.A. Colson Papers. D5830 (Miscellaneous) Mortlock Library, Adelaide.

Edwards, W.H. 1992, Patterns of Aboriginal Residence in the North-West of South Australia. Journal of the Anthropological Society of South Australia, Vol. 30, nos 1 \& 2, (December 1992), pp. 2-32.

Horne, C.J. 'Colson, Edmund Albert (1881-1950)', in J. Ritchie ed., Australian Dictionary of Biography 13 Melbourne University Press. Melbourne, 1993. 
Shephard, Mark. 1992, The Simpson Desert: Natural History and Human Endeavour. The Royal Geographical Society of Australasia (South Australian Branch) Inc., Adelaide. 1992.

Terry, Michael, 1930, Log of Michael Terry: Leader of Endeavour Mining Co. Expedition to Petermann and Tomkinson Ranges, 1930. Held by the Library of The Royal Geographical Society of Australasia (South Australian Branch) Inc., Adelaide. 